\title{
SOLVENCY TEST IN POLISH SIMPLE JOINT-STOCK COMPANY: A REVIEW AND COMPARATIVE ANALYSIS
}

\author{
Andrzej Herbet \\ Natalia Wielgat
}

\begin{abstract}
The subject of the article is a comparative analysis of the solvency test - a legal instrument that conditions causa societatis payments for limited liability companies upon ascertaining their impact on its future liquidity (ability to pay debts as they come due), which has recently been incorporated into the Polish legal system with reference to a simple joint-stock company (pol. Prosta Spółka Akcyjna) (Article $300^{15} \$ 5$ of Polish Commercial Companies Code). Considering that the solvency test originated in common law, the comparative analysis of the instrument in question was set against the background of selected foreign legal systems, i.e., the law of New Zealand, United States and the United Kingdom, where the solvency test is shaped much differently than the polish one.
\end{abstract}

Keywords: solvency test, Article $300^{15}$ CCC, distribution to shareholders, legal capital, creditor's protection

Dr. habil. Andrzej Herbet, Associate Professor, Faculty of Law, Canon Law and Administration, The John Paul II Catholic University of Lublin; correspondence address: Al. Racławickie 14, 20-950 Lublin, Poland; e-mail: andrzej.herbet@kul.pl; https://orcid.org/ 0000-0002-5835-7438.

* Natalia Wielgat, M.A., Ph.D. candidate, Institute of Law Studies, Polish Academy of Science; correspondence address: ul. Nowy Świat 72, 00-044 Warsaw, Poland; e-mail: natwielgat@gmail.com; https://orcid.org/0000-0003-2077-8672. 


\section{INTRODUCTION}

For at least two decades, the solvency test attracts a lot of interest among company law doctrine and legislators all over the world. It is considered to be an answer to large-scale criticism of the legal capital regime and its ineffectiveness with respect to safeguarding limited liability companies' creditors' interests. The solvency test, which in the context discussed by this article can be defined as a corporate law mechanism aimed at restricting causa corporationis payments leading to the loss of company's liquidity, was first recognized by English law and later developed, in particular, in the United States and New Zealand. Recently, it has been also incorporated in the Polish Commercial Companies Code as a result of the adoption of the Act amending the Act - Commercial Companies Code and certain other acts of 19 July $2019^{1}$. Considering that the title instrument has been successfully functioning for decades in common law legal systems, where it is considered to be the most effective test for regulating corporate payments ${ }^{2}$, this Article presents the Polish construction of the solvency test in comparison with selected foreign legislation of United States, New Zealand and the United Kingdom.

\section{POLISH REGULATIONS ON SIMPLE JOINT-STOCK COMPANIES}

On July 1, 2020, when the Amending Act came into force, a new, third type of limited liability company - the simple joint-stock company (PSA; Articles $300^{1}-300^{134}$ Commercial Companies Code ${ }^{3}$ ) was intro-

1 Journal of Laws 2019, item 1655, as amended; hereinafter: the Amending Act. The Act finally entered into force on 1 July 2021. The change of the originally specified date of entry into force resulted from Article 15 point 12 of the Act Amending the Act - Code of Civil Procedure and Certain Other Acts of 13 February 2020 (Journal of Laws of 2020, item 288) and Article 7 of the Act on Amending the Act - Code of Administrative Procedure and Certain Other Acts of 21 January 2021 (Journal of Laws of 2021, item 187).

John B. Heaton, "Solvency Test," The Business Lawyer 62, no. 3 (2007): 987, http://www.jstor.org/stable/40688428.

Journal of Laws of 2020, item 1586, as amended; hereinafter: CCC. 
duced into the Polish legal system. The special features of the simple stock company include above all: resignation from a fixed legal capital which was replaced with a variable share capital ${ }^{4}$, introduction of non-par value shares, allowance of contributions with no balance-sheet capacity, and changes in the rules governing the distribution to shareholders (see Articles $300^{2}-300^{3}$ and Articles $\left.300^{15}-300^{21} \mathrm{CCC}\right)^{5}$. The changes were aimed, inter alia, at facilitating causa societatis payments, making them more flexible, since in PSA they can also be made at the expense of capital contributions ${ }^{6}$.

The changes to the distribution regime are a consequence of the departure by simple joint-stock company from the legal capital regime along with its statutorily fixed minimum amount. The share capital of a PSA is not permanent ${ }^{7}$. Although it constitutes the company's obligatory basic equity (pol. podstawowy kapitat wtasny) within the meaning of the Accounting Act ${ }^{8}$, to which the shareholders' monetary and non-monetary contributions are made, it can be returned to the shareholders as part of dividend payment (Article $300^{15} \mathrm{CCC}$ ), share redemption (Article $300^{44}$ $\$ 4$ CCC) or purchase of the company's own shares (Article $300^{47} \$ 2$ point 3 CCC) $)^{9}$.

From the discussed point of view the basic provision constitutes Article $300^{15}$ CCC. Pursuant to $₫ 1$ of this Article, a shareholder is entitled

4 Andrzej Herbet, "Kapitał akcyjny prostej spółki akcyjnej i jego funkcje," in Kodeks spótek handlowych po 20 latach, ed. Marek Leśniak, Bogusław Sołtys, and Maciej Skory (Wroclaw: Wolters Kluwer, 2021), in print.

5 Explanatory Memorandum to the Draft Law on Amendments to the Commercial Companies Code and Certain Other Acts of 12 February 2019 (parliamentary print no. 3236/VIII cad.; hereinafter: Explanatory Memorandum), 1-2. See also the analysis of simple joint-stock company capital structure by Adam Opalski, "Prosta spółka akcyjna - nowy typ spółki handlowej (część I)," Przegląd Prawa Handlowego 11 (November 2019): 7-12.

6 Explanatory Memorandum, 1-2, 10 and 17.

7 In other words, the principles of full coverage and maintenance of legal capital rooted in German doctrine do not apply to the PSA share capital (inviolability; German: Kapitalaufbringung und -erhaltung).

8 Accounting Act of 29 September 1994 (Journal of Laws 2021, item 217 as amended).

9 Although the legislator has not chosen to introduce such a uniform concept, for the purposes of further considerations regarding polish CCC regulations by "distribution" we will understand all the above-mentioned types of benefits (in normative terms of "distributions") made causa societatis. 
to a share in company's profits and to a distribution from the share capital in the amount resulting from the annual financial statement, which was designated for distribution in the shareholders' resolution (unless the articles of association provide otherwise). Pursuant to $\$ 2$ of Article $300^{15}$ CCC, which sets forth the rules of the so-called balance sheet payment test, the amount to be distributed to shareholders may not exceed the sum of the last financial year profit, undistributed profits from previous years, reserves created from the profit which may be designated for dividends, and the amount from the share capital designated for dividends. This sum must be reduced by uncovered losses, company's own shares and the last financial year profits that - according to law or the company's statute should be allocated to reserves undesignated for dividends. Therefore, when it comes to PSA the CCC allows for a considerably unrestricted payout from its share capital, especially by previous standards that still apply to other polish limited liability companies, however subject to some further conditions. Firstly, a distribution from the share capital may not reduce the amount of that capital below PLN 1 (Article $300^{15} \$ 4$ CCC). Secondly, if a part of share capital constituting $5 \%$ of the company's liabilities resulting from the last approved financial statement is to be impaired by the payment, the company should conduct a special convocation proceeding (pol. postępowanie konwokacyjne) within the meaning of Article $456 \$ 1$ and 2 CCC, in order to satisfy or secure the creditors' rights (see Article $300^{15} \$ 4$ sentence 2 CCC). Thirdly, according to Article $300^{15}$ $\$ 5$ CCC, which is central to these considerations, payment to shareholders must not lead to the company losing, under normal circumstances, its ability to fulfill its due monetary obligations within six months from the date of the payment.

While Article $300^{15} \$ 5$ CCC resembles. to a certain extent, a construction of "testing" the company's solvency, treated as a condition of causa societatis legality known to foreign legal systems, the Explanatory Memorandum of the Amending Act does not indicate directly any foreign legal models which would constitute an inspiration for the Polish legislator in regard to the solvency test, even though it does refer to the American legal system with respect to other Amending Act solutions ${ }^{10}$. In this context,

10 Cf. Explanatory Memorandum, 7, 17 and 87. 
it is important to notice the laconic nature of the regulation finally adopted in Article $300^{15} \$ 5 \mathrm{CCC}$ and its deviation from the typical construction of a solvency test, which is particularly vivid against the background of comparative regulations. And this is not just about reservations raised by local legal doctrine concerning the lack of clear criteria for preparing a solvency forecast ${ }^{11}$. It needs to be emphasized that Article $300^{15} \$ 5$ CCC expresses only a simple prohibition rule: payment to shareholders may not lead to the company losing its ability to perform its financial obligations within a specified time horizon of 6 months from the payment date. When the legal norm is composed in this manner, only the loss of the ability to perform due monetary obligations within 6 months from the date of the payment remaining in a causal relationship with the payment, should be deemed unacceptable - and at the same time sanctioned by other CCC provisions ${ }^{12}$. Strictly speaking, considering the Article under review, it is difficult to even speak of a "solvency test" in the sense of this term as developed by foreign legislation.

The analyzed provision does not specify the addressee of the norm contained therein, does not specify the manner or form in which the "test" is to be carried out, does not explicitly require that a separate resolution of management in this regard should be adopted, nor does it require for a so-called "solvency certificate" to be issued or published - which might be important from the creditors', as well as shareholders and directors perspective, regarding their potential liability for a wrongful payment. In other words, the terms and conditions of solvency test are left to the company's discretion.

Despite the lack of a clear indication in this regard, it should be stated that the primary addressee of the prohibition arising from Article $300^{15} \$ 5$ CCC is the company's management board (board of directors), which is

11 The lack of clear criteria for conducting a solvency test was already pointed out with the respect to drafted reform of limited liability company capital structure in 2010, see Jowita Gajownik-Zienkiewicz, "Kilka uwag o teście wypłacalności," Przegląd Prawa Handlowego 9 (September 2011): 55-56.

12 Since the standard is formulated in the convention "It shall not be the case that in circumstances $\mathrm{X}$ it is unlawful for effect $\mathrm{Y}$ to occur", it will only be a breach of the prohibition if unlawful effect $Y$ occurs in circumstances X. This finding is fundamental in determining the rules of liability for wrongful payment from PSA capital under CCC. 
responsible for executing the relevant resolution and making the distribution. This is confirmed by the Explanatory Memorandum, which explicitly indicates - although a bit exaggeratedly - that a forecast of the company's solvency will "have to" be made by the company's management board before each planned distribution, assuming normal circumstances ${ }^{13}$.

Indeed, preceding further considerations, it should be noted that the management board - especially aiming to limit or eliminate the risk of its personal liability or trying to find grounds for refusal of dividend payment - should make such an assessment. Nevertheless, pursuant to the analyzed regulation, it is also possible for the board to neglect the forecast, hoping the insolvency will not occur within the indicated period of time. Since it is only forbidden to make a payment that subsequently led to the company loss of its ability to fulfill due monetary obligations if the company's ability to pay is not impaired, the liability of the directors or the shareholders will not be triggered even in the absence of the test. From the shareholders' point of view, however, contrary to popular opinion, the prerequisite for making a distribution (a condition for the maturity of the dividend payment claim) is not the positive outcome of the company's future solvency forecast, but its negative outcome (finding that the distribution may lead to a loss of the ability to perform due monetary obligations) that abrogates its maturity.

The management board decision made at the end of the assessment should take a form of resolution, which does not arise from the wording of Article $300^{15} \$ 5$ CCC, but from the general rules governing the functioning of this corporate body. In the absence of a different statutory, contractual or regulatory norm, the decision shall be made by a simple majority of votes (art. $300^{58} \$ 4 \mathrm{CCC}$ ). It is worth ensuring that the said resolution contains an appropriate justification, citation of materials, analyses, or opinions constituting its basis, while the minutes of the management board meeting shall specify the result of the individual votes cast.

As already noted, in contrast to many other contemporary legal systems and the original text of the draft amending $\mathrm{CCC}^{14}$, the results of

13 Explanatory Memorandum, 36.

14 According to the original assumptions, Articles $300^{15} \$ 5$ and 6 of CCC were to oblige the management board of the company to make a resolution that states the legality of 
the solvency test conducted by PSA management does not need to be public. The solvency test does not need to be carried out in any particular form or public procedure at all, nor does it have to be published by filing it to the registry court or on the company's website. As consequence, trading participants will not be able to know and assess the grounds of the payment or to assess the economic assumptions on company's condition used to justify the payment.

The fundamental issue for the application of Article $300^{15} \$ 5 \mathrm{CCC}$ will undoubtedly be the understanding of the prognosis objective and the effect (company's financial stage) prohibited by it, i.e., the loss of the company's capacity to fulfill due monetary obligations. The expression used in Article $300^{15} \$ 5$ CCC is based on Article 11 par. 1 of the Act on the Insolvency Law of 28 February $2003^{15}$, which introduces the basic definition of the debtor's insolvency, justifying the filing of the bankruptcy petition. As the Explanatory Memorandum emphasizes, the introduced restriction on dividend payments is aimed at "correlating the regulations of the corporate law with the provisions of the insolvency law (...), by eliminating the cases in which payments are made <on the vicinity> of company insolvency or even directly causing this effect" ${ }^{16}$. The conclusion that the solvency test will determine whether, as a result of a distribution, the company will not become insolvent within the meaning of Article 11 par. 1 of the Insolvency Act does not, however, solve all the questions arising in this context. This is because the interpretation of the provision cited and, consequently, the qualification of the state of insolvency is not entirely unambiguous ${ }^{17}$

the payment in whole or in part, while the resolution itself should be submitted to the registration court. Marcin Mazgaj, in Kodeks spótek handlowych. Komentarz, ed. Zbigniew Jara (Warsaw: C.H. Beck, 2020), comment to Article $300^{15}$, side no. 34 .

15 Journal of Laws 2020, item 1228, hereinafter: Insolvency Act.

16 See Explanatory Memorandum, 26.

17 See for example: Rafał Adamus, Prawo upadtościowe. Komentarz (Warsaw: C.H. Beck, 2019, Legalis). See also: Supreme Administrative Court, Judgment of 28 April 2006, Ref. no. V CSK 39/06, Legalis; Piotr Zimmermann, Prawo upadtościowe. Prawo restrukturyzacyjne. Komentarz (Warsaw: Wolters Kluwer, 2020, Legalis); Patryk Filipiak, in System Prawa Handlowego. Prawo restrukturyzacyjne i upadtościowe, ed. Anna Hrycaj, Andrzej Jakubecki, and Antoni Witosz (Warsaw: C.H. Beck, 2019), 724. See also the decision of Supreme Administrative Court, Judgment of 14 June 2000, Ref. no. V CKN $1117 / 00$, Legalis. Cf. an interesting proposal of insolvency interpretation presented by $\mathrm{Ar}-$ 
- both in the context of the understanding of the "ability" to perform due monetary obligations and sustainability of this state. For the purpose of these considerations, the interpretation of the notion of insolvency based only on linguistic directives seems to be insufficient. When assessing insolvency, one cannot limit oneself to the analysis of the current state but has to examine both, the perspective of the probable improvement of the debtor's financial situation and the negative perspective, because in some cases the debtor may lose the ability to meet its financial obligations before the first unfulfilled obligation comes due ${ }^{18}$. Moreover, the Insolvency Act is aiming at examining insolvency ex post, and not ex ant. Therefore, in this context, it seems to be an open question whether, given the protective function of the Article $300^{15} \$ 5$ CCC, it would not be more appropriate to refer to the "threat of insolvency" within the meaning of Article 6 par. 3 of the Act on Restructuring Law of 15 May $2015^{19}$.

Considering the above, an equally significant shortcoming of the new Polish regulation is the accepted 6-month time horizon, within which the company should not, under normal circumstances, lose its ability to perform its due monetary obligations, which is far too short ${ }^{20}$. Apart from the fact that economic theory has developed a number of reliable (albeit complicated) models for the prediction of insolvency over a much longer time horizon ${ }^{21}$, it is crucial to note that a statement of this type,

tur Nowacki, "Niewypłacalność płynności jako przesłanka ogłoszenia upadłości,” Przegląd Prawa Handlowego 8 (September 2020): 4-12.

18 Marcin Kubiczek and Bartosz Sokół, "Metodyka badania płynnościowej przesłanki niewypłacalności w świetle jej prawnej definicji," Doradca Restrukturyzacyjny, no. 1 (2016): 107-109. At this point it is worth noting that on the basis of Article 11 par. 1 of Insolvency Act, it is traditionally acknowledged that in order to state insolvency, it is necessary to cease to perform at least two obligations towards two different creditors. However, this is not a uniform and unquestionable view. Cf. Patryk Filipiak, in Prawo restrukturyzacyjne. Komentarz, ed. Patryk Filipiak and Anna Hrycaj (Warsaw: Wolters Kluwer, 2020, Lex), comment to Article 11. Cf. also Supreme Administrative Court, Judgment of 19 May 2019, Ref. no. III UK 85/18 (Lex no. 2642120).

19 Journal of Laws 2020, item 814, hereinafter: Restructuring Act.

20 In a similar direction, Mazgaj, Kodeks spótek handlowych, comment to Article $300^{15}$, side no. 33, advocating the originally proposed one-year estimation horizon.

21 See Elżbieta Mączyńska and Maciej Zawadzki, "Dyskryminacyjne modele predykcji upadłości przedsiębiorstw," Ekonomista 2 (2006): 205-235; Elżbieta Mączyńska, "Oce- 
with a 12-month assessment horizon, is submitted annually by the management board for the purpose of auditing and approving the financial statements and the management report. Indeed, it is only the possibility of making the going concern assumption, that allows the application of the general principles for the valuation of the company assets (see Article 5 par. 2 of the Restructuring Act, $\$ 25$ of International Accounting Standards No. 1 "Presentation of Financial Statements", International Auditing Standard 570(Z) and National Auditing Standard 570(Z) "Going Concern" $)^{22}$. The evaluation horizon of 6 months does not even coincide with the balance sheet classification of liabilities or assets as current liabilities or current assets.

Furthermore, such a radical shortening of the solvency forecast does not seem to be justified when considering the literal wording of Article $300^{15} \$ 5$ CCC, according to which a payment to shareholders must not lead to insolvency "under normal circumstances". In other words, the payment will not be considered unlawful if the loss of the ability to perform due monetary obligations will emerge due to "extraordinary" circumstances. Performing a solvency test requires considering the current and anticipated financial situation of the company and its economic environment in the context of a normal, i.e., typical pattern of economic phenomena, without any obligation to take account of exceptional circumstances, unforeseeable for a diligent manager, as sudden collapse of sales markets, a jump in inflation, or the unexpected insolvency of major contractors ${ }^{23}$. However, it goes without saying that the requirement of acting with due

na kondycji przedsiębiorstwa: Uproszczone metody,” Życie Gospodarcze 38 (1994): 42-45; Błażej Prusak, Nowoczesne metody prognozowania zagrożenia finansowego przedsiębiorstw (Warsaw: Difin, 2005), 7 et seq., and in legal studies: Mirosław Marek, Paweł Multaniak, Błażej Piechowiak, and Anna Szymańska, in Postępowanie restrukturyzacyjne. Komentarz praktyczny. Wzory pism i przyktady postępowań restrukturyzacyjnych, ed. Andrzej Głowacki and Cezary Zalewski (Warsaw: C.H. Beck, 2020), 53 et seq.; Michał Żurek, Reforma regulacji prawnej kapitatu zaktadowego spótki z ograniczona odpowiedzialnościq. Problematyka ochrony wierzycieli (Warsaw: C.H. Beck, 2018), 192 et seq.

22 The latter constitutes Appendix no. 1.24 to Resolution no. 3430/52a/2019 of the National Council of Statutory Auditors of 21 March 2019.

23 Similarly Mazgaj, Kodeks Spótek Handlowych, comment to Article $300^{15}$, side no. 32; Małgorzata Wawer, in Kodek spótek handlowych. Komentarz, ed. Jacek Bieniak, Michał Bieniak, Grzegorz Nita-Jagielski, Krzysztof Oplustil, Robert Pabis, Anna Rachwał, 
diligence (Article $300^{54} \mathrm{CCC}$ ) indicates that in assessing "normal circumstances" one should refer to the state of knowledge that a member of the company's management board has or should have, performing his/ her duties in a manner consistent with this yardstick: acting diligently and loyally towards the company. This means that circumstances that are extraordinary, but at the same time known to the board member, not only can but should be considered.

The last issue to be discussed in the context of the new Polish regulations are the liability for unlawful causa societatis payouts. Firstly, the PSA shareholders are obliged to return the wrongful payment (Article $300^{22} \$ 1$ and 2 CCC). Secondly, the management board members who approved (allowed) the payment are jointly and severally liable for its return. This liability exists only towards the company and in practice will usually occur in the event of a change of control or declaration of company's bankruptcy when the claims in question will be submitted by a receiver. Referring to the previous remarks, it has to be remembered that payment is in breach of Article $300^{15} \$ 5$ CCC if within 6 months from its date and as a result of it, the company, acting under normal circumstances, loses its ability to fulfill due monetary obligations. What might be surprising, from the shareholder's point of view the obligation to return the funds will arise both in the case of failure to carry out, a defective carrying out as well as a correct carrying out of the solvency test and the good faith of a shareholder is of no importance. It only determines the length of the limitation period for the claim (see Article $300^{22} \$ 4$ CCC). The fact of conducting the solvency test in a proper manner will be significant only for management board members whose liability is based on the principle of fault (presumed, similarly as in the case of ordinary contractual liability). Thus, a director will be able to defend him/herself against a claim for reimbursement of an unlawful payment by proving that his/her act or omission was not culpable.

Marcin Spyra, Grzegorz Suliński, Marcin Tofel, Małgorzata Wawer, and Robert Zawłocki (Warsaw: C.H. Beck, 2020, Legalis), comment to Article 300 ${ }^{15}$, side no. 14. 


\section{UNITED STATES - MODEL BUSINESS CORPORATION ACT}

Both the solvency test itself and the legal solutions accompanying it are shaped much differently in the common law legal system. Since it is safe to say that most foreign legislatures that adopted an instrument in question in recent decades have modeled their solutions up to some point on American law, the comparative analysis should begin with the Model Business Corporations $\mathrm{Act}^{24}$ provisions, that constitutes a model set of rules, regularly amended and accompanied by extensive official commentary, adopted by the vast majority of U.S. state corporate $\operatorname{codes}^{25}$.

According to $\$ 6.40(\mathrm{c})(1) \mathrm{MBCA}$, which governs distributions to a business corporation's shareholders, no distribution may be made if, after giving it effect, the company would not be able to pay its debts as they become due in the usual course of business. The solvency test is enforced by enhanced net asset test $(\$ 6.40(\mathrm{c})(2) \mathrm{MBCA})$, according to which after the payment the corporation's total assets cannot be less than the sum of its total liabilities plus (unless the articles of incorporation permit otherwise) the amount that would be needed, if the corporation were to be dissolved at the time of the distribution, to satisfy the preferential rights upon dissolution of shareholders whose preferential rights are superior to

24 American Bar Association. Committee on Corporate Laws, Model Business Corporation Act: Official Text with Official Comment and Statutory Cross-References, (December 2020), https://www.americanbar.org/content/dam/aba/administrative/business_law/ corplaws/2020_mbca.pdf.\%20Hereinafter:\%20MBCA. The origin of the solvency test, understood as a tool to regulate the mechanisms for dividends payment, dates back to the mid-1970s, when members of the American Bar Association - Committee on Corporate Laws pointed out the need to move away from the principles of maintenance and inviolability of the legal capital to flexible regulations relating to the maintenance of liquidity and balance sheet surplus of the company. Larry Scriggins, "The Model Business Corporations Act Financial Provisions: A Historical Snapshot," Law and Contemporary Problems 76 (Winter 2011): 125.

25 Due to the federal character of the United States, local legal system has a two-tier character, where the company law is regulated separately at the level of each U.S. state. Nevertheless, the legislatures of more than 40 U.S. states have based their dividend law provisions on the MBCA. Business Law Section Corporations Committee the State Bar of California, Revisions to Streamline and Update Corporation Code Provisions Relating to Distributions and Repurchases of Shares Legislative Proposal (bls-2011-01) (April 2010): 9. 
those receiving the distribution. The term "distribution" used in $\$ 6.40$ MBCA defines the scope of the payment test, and it is understood broadly, since a distribution might take the form of a dividend, a payment in respect of the purchase, redemption or other acquisition of company's own shares, the repayment of debts, a liquidation payment or any other form $(\$ 1.40 \mathrm{MBCA})^{26}$.

The solvency test regulated by MBCA is more detailed than the Polish solutions, outlining the rule governing evaluation procedure. Both the admissibility of the payment and its date is determined by the board of directors. In principle, the effect of a distribution is measured as of the date of its authorization, but only if the payment occurs within 120 days after the date of authorization ( $\$ 6.40$ (e)(3) MBCA). Therefore, after 4 months it is in the officers' own interest to reassess an evaluation, as its legality will be measured as of the date of the actual payment ${ }^{27}$. At the same time the MBCA, alike Article $300^{15} \$ 5$ of Polish CCC, does not explicitly oblige the directors to carry out the solvency assessment and their duty is derived indirectly from the director's standards of conduct rules. Another common feature is that officers are not formally obliged to prepare a solvency certificate or to state the result of the projection in any written or documentary form.

The range and the depth of the assessment carried out by the directors is determined by their fiduciary duties, with a key role played by the business judgement rule ${ }^{28}$. Next to the fact that $\$ 6.40(\mathrm{~d}) \mathrm{MBCA}$ indicates itself that the officers may base their appraisal on the company's financial

26 At the same time, the literature indicates that the dividend regulations of the MBCA do not cover so-called hidden distributions, since the making of such payments is not considered there in terms of violations of dividend rules, as typical to European countries, but of the fiduciary duties and voidable transactions law rules. Andreas Engert, "Life Without Legal Capital: Lesson from American Law," Working Paper, Ludwig Maximilians Universität München (27 February 2006): 25, https://papers.ssrn.com/sol3/ papers.cfm?abstract_id=882842.

27 These time limits differ slightly for other ways of making distributions from the company's assets. For instance, in case of purchase, redemption or other acquisition of the company's own shares, the effect of the distribution is measured by the date on which the distribution is made, or by the date on which the debt arises or the shareholder ceases to have the status of a shareholder. Cf. $\$ 6.40(\mathrm{e})(1)$ and (2) MBCA.

28 Cf. Article $300^{125} \$ 2$ CCC. 
statements, more detail guidance in this regard is to be found in $\$ 8.30$ $\mathrm{MBCA}^{29}$, which specifies the information that the directors may rely on, listing e.g., information, opinions, reports or statements provided by reliable employees, legal counsel or public accountants. Moreover, although, like in Poland, the legal definition of insolvency and the method of its assessment is not uniformly defined by American legal doctrine, case law generally agrees on the primacy of evaluating insolvency in the context of the loss of an entity's ability to pay its obligations as they come due ${ }^{30}$ and the official commentary to the MBCA gives some vital guidance about the test procedure itself. It recognizes that if a company's financial statements are regularly audited and the qualification of its status as a "going concern" is not endangered according to the most recent auditor's opinion as well as there are no subsequent adverse events, in most cases, it can be considered as decisive for approving a payout, since "it will be apparent from information generally available that no particular inquiry concerning the equity insolvency test in section $6.40(\mathrm{c})(1)$ is needed" 31 .

29 According to $\$ 8.30$ MBCA each member of the board of directors, when discharging the duties of a director, shall act: (i) in good faith, and (ii) in a manner the director reasonably believes to be in the best interests of the corporation. Moreover, a director is entitled to rely on, among others, one or more officers or employees of the corporation whom the director reasonably believes to be reliable and competent in the functions performed or the information, opinions, reports or statements provided, as well as legal counsel, public accountants, or other persons retained by the corporation as to matters involving skills or expertise the director reasonably believes are matters (i) within the particular person's professional or expert competence, or (ii) as to which the particular person merits confidence.

30 See e.g., Heaton, "Solvency Test," 991, where the author discusses practical difficulties in defining solvency under U.S. law. The jurisprudence indicates that when assessing the solvency of an entity, all foreseeable future financial operations of the company must be taken into consideration, as well as other circumstances such as macroeconomic returns, strong drops in sales or high value lawsuits brought against the company. As regards the assessment of the company's solvency potential immediately after the distribution, the number of liquid assets in the form of cash or cash equivalents should be compared with current liabilities. See also the ruling in F.T.C. vs. Med. Restors Intern Inc., 2000 WL 1889635 (N.D. Ill. 2000) or in re Brownstein vs. Fiberonics Industries, Inc., where the court assessed a company's insolvency by comparing its short-term claims and assets, under the assumption that short-term claims can only be paid with funds generated from liquid assets.

31 American Bar Association, Model Business Corporation Act, comment to $\$ 6.40$ MBCA. See Bernhard Pellens and Thorsten Sellholm, "Improving Creditor Protection 
Unlike the Polish solvency test, which is limited to an exceptionally short 6-month time horizon, MBCA does not prejudge the time limit for forecasting the company's liquidity, which in the literature is even sometimes interpreted as an obligation to carry out a prognosis as far into the future as to the date of maturity of the most forward-looking company's liability ${ }^{32}$. However, as a rule, case law assumes that the examination should cover a minimum period of one year, although it is often stressed that in some cases the future solvency projection should cover a much longer period ${ }^{33}$.

The liability of directors for making unlawful causa corporationis payment is governed by $\$ 8.32$ (a) $\mathrm{MBCA}^{34}$. Directors who vote for or authorize a distribution in violation of $\$ 6.40$ (a) MBCA or the corporation articles of association are personally liable for its return to the corporation's estate in excess of the amount that could have been paid legally, but only if it is proven that they violated the provisions of $\$ 8.30 \mathrm{MBCA}$ governing directors' fiduciary duties. The director held liable for an unlawful pay-

Through IFRS Reporting and Solvency Tests," in Legal Capital in Europe, ed. Marcus Lutter, European Company and Financial Law Review, Special Volume 1 (2006): 381 and Igor Komarnicki, "Ograniczenia wypłat na rzecz akcjonariuszy w prawie europejskim," in Europejskie prawo spótek - t. I. Instytucje prawne dyrektywy kapitatowej, ed. Mirosław Cejmer, Jacek Napierała, and Tomasz Sójka (Cracow: C.H. Beck, 2004), 65.

32 Christoph Kuhner, "The Future of Creditor Protection Through Capital Maintenance Rules in European Company Law," in Legal Capital in Europe, ed. Marcus Lutter, European Company and Financial Law Review, Special Volume 1 (2006): 357.

332001 WL 243537, 10 - 11 (S.D.N.Y. 2001) cited in Pellens, Sellholm, Improving Creditor Protection, 17. By way of example, the United States Bankruptcy Court, Northern District of Georgia in re Vista Eyecare indicated that the scope of the projection will vary depending on the circumstances surrounding a particular company's operations, but it covers at least the period up to the date on which the company is required to make material payments in satisfaction of existing obligations. In Pereira v. Cogan (267 Mass. 52, 165 N.E 889 (1929)), on the other hand, the court based its decision on an analysis of the entity's cash flows over a three-year period.

34 According to $\$ 8.33$ (a) MBCA a director who votes for or assents to a distribution in excess of what may be authorized and made pursuant to MBCA distribution rules is personally liable to the corporation for the amount of the distribution that exceeds what could have been distributed without violating of MBCA distribution rules, if the party asserting liability establishes that when taking the action the director did not comply with section MBCA's director's standards of conduct. 
ment is entitled to contribution from every other director who could be held liable and to the recoupment from each shareholder of the pro-rata portion of the unlawful distribution amount the shareholder that accepted the payment knowing that it was made in violation of the MBCA ${ }^{35}$. It is generally accepted that not only the directors who made the decision of illegal payment might be held liable but also those who failed to take action to prevent it or who neglected their duty of care or duty of loyalty ${ }^{36}$. What's interesting, as far as shareholders are concerned, for their liability to arise on the basis of the MBCA it is necessary for the officer to be found liable for unlawful distribution first. Therefore, their liability is subsidiary and limited by the presumption of good faith.

Although the solvency test is regarded to be the most important American criterion for corporate distributions, there is a number of judgments determining the liability for an unlawful payment based on the infringement of the MBCA. Whereas those that exist deal primarily with intra-company conflicts involving payment of dividends to majority shareholders, redemption rights, the exercise of put options, or the redemption of shares ${ }^{37}$. This results from the fact that American company law is not designed to play a direct role in creditors protection, and as a consequence, the character of shareholders liability is subsidiary and claims for unauthorized distributions must be based on a breach of directors' fiduciary duties, which violation, by the way, is often hard to prove due to the "safe harbor" of the business judgment rule ${ }^{38}$. The liability for distribution infringing solvency test rules is thus dependent on a violation of $₫ 8.30$ MBCA and, therefore, an attempt to assert a claim thereunder will require proof of a breach of the standards of conduct.

35 A claim against the remaining directors may be brought within one year of the date of the final determination of director liability under $\$ 8.33$ (a) MBCA.

36 For instance, in Calkins vs. Wire Hardware Co. (267 Mass. 52, 165 N.E 889 (1929)), the directors who were not present at the meeting at which the resolution to distribute profits was passed, were held liable on the ground that they knew of the plans to vote on the disputed distribution, which was understood to be their implied consent. In Pereira vs. Cogan, the court emphasized that abstention by directors from voting on major corporate decisions does not relieve them of liability.

37 Engert, "Life without Legal Capital," 25.

38 Ibid. 
In the context of the above, is important to notice, that as the official commentary to the article in question explains, MBCA establishes the validity of distributions from the corporate law standpoint, and this is why it determines the potential liability of directors for improper distributions under $\$ 8.30$ and 8.32 MBCA regarding its fiduciary duties. This is because it is American federal bankruptcy laws and state fraudulent conveyance statutes ${ }^{39}$ that are designed to enable the trustee or other entities to recapture for the benefit of creditors funds distributed to others in some circumstances, not the provisions of company law itself, which is crucial for understanding the systemic context and the true role of the MBCA solvency test in the USA ${ }^{40}$. Therefore, lack of need to rely on allegations of violation of $\$ 6.40$ (c) (1) MBCA results from the fact that American company's creditors are entitled to much more effective legal instruments, regulated at the level of insolvency and civil law - the voidable transactions regulations, which are similar to actio Pauliana (Articles 527 et seq. of Polish Civil Code ${ }^{41}$ ) and bankruptcy provision concerning the ineffectiveness of the bankrupt's legal acts (Article 127 et seq. of Polish Insolvency Act).

\section{NEW ZEALAND - COMPANIES ACT 1993}

In New Zealand, the growing dissatisfaction with inflexible law solutions modeled so far on the English, and consequently EU, regulations, gave rise to a thorough revision of company law. As a result, the legislature adopted a new Companies Act $1993^{42}$, which, among others, changed the corporation's payment regulations, from then based on the MBCA solvency test ${ }^{43}$. Today, despite initial criticism and concerns about a possible

39 See $\$ 4$ et seq. of Uniform Voidable Transactions Act (formerly Uniform Fraudulent Transfer Act) (as amended in 2014), 8 March 2016 and $\$ 48$ et seq. of Title 11 of the United States Code - Bankruptcy Code.

40 American Bar Association, Model Business Corporation Act, comment to $\$ 6.40$ MBCA, point 4.

41 Civil Code of 23 April 1964 (Journal of Laws of 2020, item 1740, as amended).

42 Hereinafter: NZCA.

43 Constructs such as the assessment of solvency in the context of the "normal course of business" are taken from the MBCA. New Zealand Law Commission, Report No. 16, 
"paperwork war" accompanying the new rules on distributions of limited liability companies' profits ${ }^{44}$, the NZCA, being a result of the New Zealand Law Commission many years' work ${ }^{45}$, is regarded as a progressive legislative achievement, far more responsive to market needs than the previous norms. The New Zealand accomplishments have also found recognition among European legal doctrine, being described by the European Interdisciplinary Group on Capital Maintenance as "impressive" 46.

Alike in most modern legal systems, the NZCA solvency test is accompanied with the balance sheet test. Whereas the second one is fairly detailed, the solvency itself is framed succinctly, as it indicates that the company must be able to pay its debts as they become due in the normal course of business. Therefore, if the board of directors is satisfied on reasonable grounds that the company will, immediately after the distribution, satisfy the solvency test, it may authorize distribution by the company at a time, and of an amount, and to any shareholders, it thinks fit ( $\$ 52$ NZCA).

As defined in $\$ 2$ NZCA, "distributions" include dividend payments, share redemption payments, payments for the acquisition of the company's own shares, and financial assistance procedure (Part 6 of NZCA) ${ }^{47}$. The solvency test will also apply when carrying out a merger of companies

Company Law Reform: Transition and Revision (September 1990): 18, www.lawcom.govt. $\mathrm{nz} /$ sites/default/files/projectAvailableFormats/NZLC\%20R16.pdf. Report no. 16 is a supplement to Report no. 9.

44 Michael J. Ross, "Evaluation New Zealand's Companies Law," Agenda: A Journal of Policy Analysis and Reform 1, no. 2 (1994): 192.

45 The New Zealand Law Commission was established in the 1980s. In 1989 the commission submitted a comprehensive report proposing a major overhaul of the New Zealand company law system, eliminating the flaws and inefficiencies of the legal capital-based system.

46 Jonathan Rickford, "Reforming Capital. Report of the Interdisciplinary Group on Capital Maintenance,” European Business Law Review 15 (April 2004): 979. Interdisciplinary Group on Capital Maintenance was established in May 2003 to review company law on capital maintenance and developing accounting standards.

47 According to $\$ 2$ NZCA, in relation to a distribution by a company to a shareholder, the distribution means direct or indirect transfer of money or property, other than the company's own shares, to or for the benefit of the shareholder; or the incurring of a debt to or for the benefit of the shareholder, in relation to shares held by that shareholder, and whether by means of a purchase of property, the redemption or other acquisition of shares, a distribution of indebtedness, or by some other means. 
pursuant to Part 13 of NZCA, or when transferring the company's seat pursuant to Part 19 of NZCA. The doctrine also points out that the wording of the definition of "distribution" (i.e., distribution "(...) in relation to shares held by that shareholder") indicates that the solvency test also covers non-corporate (hidden) payments, such as payment of remuneration to the shareholder under a contract concluded with the company ${ }^{48}$.

Since the fairly "new" New Zealand solvency distribution test refers to long-known local voidable preferences rules, regulated already in 1955 . the practice of carrying out solvency test is well-established in New Zealand and the jurisprudence sets out a number of guidelines as to the principles of its conduct ${ }^{49}$, which is largely missing on the grounds of Polish regulations. Moreover, due to the above, in New Zealand the obligation to assess the impact of a planned payment on the company's liquidity was derived from case law many years before the introduction of the NZCA. Nevertheless, the most significant change proposed by the act was the requirement of drawing up the directors' solvency certificate. Currently, $\$ 52$ NZCA requires directors voting in favor of distribution to prepare and publish a solvency certificate which includes a statement that, in their opinion the company will, immediately after the distribution, satisfy the solvency test. As part of the certificate, the directors are required to provide justification for the assessment. The justification should be precise, detailed, and include separate explanations to confirm that the company meets the balance sheet and liquidity criteria of the payout test $\mathrm{t}^{50}$. The obligation to prepare, carefully justify and publish a statement of solvency accompanying every corporate distribution from the company's assets undoubtedly reinforces the New Zealand solvency testing rules, giving them a real value in terms of creditor protection.

The New Zealand liability rules for breach of the solvency test requirements are much more clearly structured and better adjusted to the role of creditor protection than Polish ones. If a company did not meet the re-

48 See more Christopher I. Haynes, "The Solvency Test: A New Era in Directorial Responsibility," Auckland University Law Review 7 (1996): 127.

49 Ross, "Evaluation New Zealand's," 192.

50 Haynes, "Solvency Test," 135. At the same time, it is permissible to draw up a single certificate to be signed by all the members of the board of directors and separate documents for each officer, signed on the same terms as the joint certificate ( $\$ 394$ NZCA). 
quirements of the solvency test on the payout date, the amount unlawfully paid shall be in the first place returned to the company's estate by its' beneficiaries. They may only be relief from the obligation to return the payment under fulfillment of three cumulative conditions: (1) receiving the payment in good faith, with no awareness of the company's violation of legal regulations, (2) raising of doubts about the legality of the payment, and (3) a change in the shareholder's situation to such an extent that it would be unfair to require him to return the unlawfully made payment in full or at all ( $\$ 56$ (1) NZCA). In practice, the cumulative fulfilment of the above requirements may prove difficult, especially for companies with dispersed shareholders conducting large-scale operations. Undoubtedly, however, the severity of these conditions furtherly reinforces the protective role of the discussed instrument. At the same time, if during the trial the court becomes convinced that the company could, by making a distribution of a lesser amount, have satisfied the solvency test, the court may permit the shareholder to retain an amount equal to the value of any distribution that could properly have been made ( $\$ 56(5)$ NZCA).

As for the liability of the directors, under $\$ 56$ (2) NZCA, a director is personally liable to the company for the repayment of a distribution made to shareholders that do not comply with the NZCA up to an amount that cannot be recovered from the shareholders if, in connection with the distribution: the payout test procedures were not followed, or the payout was made despite there being no indication that the company would reasonably be expected to meet the test at the time the certificate was signed, and at the same time the director did not take reasonable steps to ensure that the procedure for making the payout was followed, or he/she signed the certificate in circumstances that did not justify making the payout. The liability of officers is therefore personal, subsidiary and concerns both the failure to comply with the procedure as well as the misjudgment of the company's maintenance of liquidity after the payout. Also, with respect to officers if, in an action brought against them the court is satisfied that the company could, by making a distribution of a lesser amount, have satisfied the solvency test, the court may relieve the director from liability in respect of an amount equal to the value of any distribution that could properly have been made. In addition, directors convicted of an offense against distribution to shareholders provisions are liable to a fine 
not exceeding 5,000 NZD ( $\$ 373$ (1)(4) NZCA). Directors are subject to the same penalty if they fail to prepare a solvency certificate on time, as well as for failing to state the grounds of their decision. Moreover, a director who prepares a solvency assessment that is false, or misleading is liable to imprisonment for a term not exceeding 5 years or a fine not exceeding 200,000 NZD (\$ 377 (1) and $\$ 373$ (4) (c) of the NZCA).

\section{UNITED KINGDOM - COMPANIES ACT 2006}

The increasing regulatory competition which took place in the last decades among EU Member States has also led to a liberalization of United Kingdom law under which the Company Law Reform Steering Group proposed a significant revision of company law, broadly concerning a private limited company $(\mathrm{Ltd} .)^{51}$. The reform objective was to loosen the legal capital regime and strengthen the company's creditor's protection ${ }^{52}$. The changes included the introduction of an optional solvency testing procedure.

Although the British solvency test regulated in Companies Act $2006^{53}$ does not apply to a dividend payment, which is limited by a retained earnings test (830 et seq. CA), it does apply to other causa corporationis payments, i.e., the procedure of share capital reduction and the redemption or acquisition of companies own shares. Previously, the capital reduction procedure had to be approved by the court. Now, a private company limited by shares may reduce its share capital also by special resolution supported by a solvency statement $(\$ 641(1)$ (a) CA). However, the decision to reduce the capital is still made by the shareholders' meeting, it must be preceded by a directors' solvency statement. Despite the initial recommendations of the Company Law Reform Steering Group, that conducting of the solvency test and certification of its result should fully replace the capital

51 The regulations came into force on 1 October 2009.

52 Jennifer Payne, "Legal Capital in the UK Following the Companies Act 2006. Rationality In Company Law: Essays In Honour Of D.D. Prentice, J. Armour and J. Payne, eds., Hart Publishing," Oxford Legal Studies Research Paper, no. 13 (October 2008): 1, 42, https://ssrn.com/abstract=1118367.

53 Hereinafter: CA. 
reduction mechanism based on court approval, currently these regulations constitute only an alternative ${ }^{54}$. Also, a payment out of capital by a private company for the redemption or purchase of its own shares is not lawful unless: (1) directors' solvency statement and auditor's report is provided, (2) it is approved by a special resolution, (3) public notice of proposed payment is made, and (4) the directors' statement and auditor's report are available for inspection ( $\$ 713(1) \mathrm{CA})$.

What is characteristic for both British and New Zealand solutions, and what constitutes a significant weakness of Polish regulations, is that the English solvency test rules focus strongly on the solvency certification procedure, requiring a company's directors to form an opinion on the company's ability to meet its debts after the payment. The content of an English solvency statement is shaped similarly to the statement submitted in connection with the repealed financial assistance procedure (the socalled financial assistance "whitewash" procedure ${ }^{55}$ ), except the fact that currently the statement on reduction of the company's capital does not have to be accompanied by an auditor's report, although it is required in case of redemption or acquisition of the company's own shares ${ }^{56}$. The $\$ 643$ CA specifies the content of the document, declaring that it is a statement where each of the directors had formed the opinion, as regards the company's situation at the date of the statement, that there is no ground on which the company could then be found to be unable to pay (or otherwise discharge) its debt. When it is intended to commence the winding up of the company within twelve months of the payment date, the directors are obliged to state that the company will be able to pay (or otherwise discharge) its debts in full within this period of time. In any other case, that the company will have to be able to pay its debts as they fall due during the year immediately following that payout ( $\$ 643$ (1) CA).

The solvency statement prepared for the purposes of capital payment for the redemption or purchase of private company own shares shall be prepared in a bit different manner since according to $\$ 714(3) \mathrm{CA}$,

54 Company Law Reform Steering Group, Company Formation and Capital Maintenance (URN 99/1145), \$3.27.

55 Cf. $\$ 115$ Companies Act 1985.

56 Payne, “Legal Capital in the UK,” 26. See $\$ 643$ Companies Act 1985. 
the directors' having made a full inquiry into the affairs and prospects of the company need to declare that immediately after the date of the proposed distribution, there will be no reason to believe that the company will not be able to pay (or otherwise discharge) its liabilities, and in respect of the prospects of the company for the year following the date of the distribution, the company will be able to carry on business on a going concern basis ("as a going concern") and meet its liabilities as they fall due. The assessment needs to take into account the intention of the directors in relation to the management of the company during that year and the quantity and nature of financial assets which the directors believe will be available to the company during that year.

As indicated, the British construction of the solvency statement takes a specified time perspective limited to a period of one year. When the company is expected to be wound up within one year of the date of the statement, the directors are forced to change their perspective by estimating the company's ability to settle all its liabilities, not just those that will arise within the said period. Analyzing the solvency of the company, the directors should consider contingent and future liabilities $(\$ 643(2)$, $\$ 714$ (4) CA), excluding extraordinary events ${ }^{57}$.

The solvency statement shall be prepared not less than 15 days before the date of the relevant shareholders' resolution. Where a resolution is passed in writing, a copy of the directors' statement shall be sent or given to each shareholder entitled to vote before or at the time of the vote. Where the resolution is passed at a meeting, a copy of the solvency statement shall be made available for inspection during the meeting. The solvency statement shall include the date on which it is signed and the name of each director of the entity ${ }^{58}$. Furthermore, a copy of the solvency statement shall be delivered to the Registrar of Companies within 15 days of the shareholders' meeting resolution together with a statement of capital. However, failure to provide the aforementioned documents to the Regis-

57 Ibid, 39.

58 The English literature indicates that the legislature's use of the phrase "each director" may suggest an obligation for so-called de facto directors to sign the statement as well. Brenda Hannigan, Company Law (Oxford: Oxford University Press, 2018), 600. Cf. the ruling in Flap Envelope Co Ltd, Cook vs. Green ((2009) BCC 204). 
trar, including the statement of solvency itself, does not affect the validity of the resolution. Similarly, the resolution remains valid if the board of directors fails to comply with its obligation to provide the shareholders with a certificate when passing the resolution ( $\$ 644 \mathrm{CA})$.

Whereas the liability of the recipients of a wrongful dividend is governed by $\$ 847(2) \mathrm{CA}$, which oblige the shareholders to return to the company's assets any distribution made in contravention of the law to the extent that, at the time of the distribution, they knew or had reasonable grounds to believe that such distribution had been made in breach of the law, this rule does not apply to any payment made by a company in respect of the redemption or purchase by the company of shares in itself $f^{59}$. Nonetheless, in this regard, the literature points to the case law that indicates the invalidity of an unauthorized return of capital, even in the case of procedural failures ${ }^{60}$. Irrespective of this, the doctrine argues for an explicit regulation of the wrongful payment consequences at the statutory level ${ }^{61}$.

The officer's liability rules are clearer than those concerning company's shareholders. Taking as an example a share capital reduction procedure, if the board of directors has prepared a solvency statement without reasonable grounds for the opinion contained therein, and the statement has been delivered to the Register of Companies, the action of the member of the body constitutes an offense punishable by imprisonment of up to two years or a fine $(\$ 643(4)-(5) C A)^{62}$. The liability of directors is regulated in a similar manner with respect to the procedure for the acquisition or redemption of own shares ( $\$ 713 \mathrm{CA}$ ). If a solvency statement has not been presented to the shareholders, an offense is committed by any officer who has failed to perform his legal duty (\$ 644 (7) CA). Moreover, failure to comply with the other rules expressed in the section on reduction of capital, is an offense committed by any officer of the entity who has failed to perform his duty ( $\$ 644$ (8) CA). A person guilty of an offense under $\$ 644$ (7) or (8) CA is liable to a fine. In addition to the sanctions cited,

59 Thomas Bachner, Creditor Protection in Private Companies Anglo-German Perspectives for a European Legal Discourse (Cambridge: Cambridge University Press, 2009), 120.

60 See MacPherson vs. European Strategic Bureau Ltd ([2000] 2 BCLC 683).

61 Payne, "Legal Capital in the UK," 41.

62 The mentioned criminal measures may be applied cumulatively. 
violation of the interests of the company's creditors may involve personal liability of the directors related to breach of fiduciary duty ${ }^{63}$.

At the end, it is important to note that even though the English regulations do not expressly regulate the prohibition of making dividend payments that could result in the company's lack of liquidity, as it is the case in all three analyzed legal systems, the prohibition of making such payouts to shareholders results from fiduciary duties imposed on the board of directors, as well as from wrongful (fraudulent) trading rules (known in New Zealand as reckless trading ${ }^{64}$ ), which are regulated at the level of company and insolvency law, and shape the prohibition on undertaking trade in the state of imminent insolvency of the company, applying financial personal responsibility for directors for its further obligations.

\section{CONCLUSIONS}

The solvency test undoubtedly constitutes an interesting instrument of company law, widely and successfully applied both in common and civil law countries. A model of protection that takes into account the necessity of conducting a prognosis of an entity's future liquidity limit the risk of making distributions to shareholder on the verge of bankruptcy, especially when compared to solutions based solely on calculations referring to the company's profit, positive balance sheet or legal capital maintenance rules. On the level of the Polish legal system, it also allows ensuring better correlation between the provisions of corporate and insolvency law. However, in the form adopted in the CCC the solvency test is subject to numerous flaws, being constructed far too laconically, with too many doubts as to its evaluation criteria and liability resulting from its infringement. A substantial objection needs to be raised against a noticeably short forecast period for the company's future solvency, which is unprecedented on the comparative background, as well as the lack of requirement to adopt a separate directors' resolution as a prerequisite for the payment claim or the lack of obligation to justify the payment decision. Therefore, the sol-

63 Payne, "Legal Capital in the UK," 41.

64 See $\$ 135$ NZCA, \$993 CA and \$ 213-214 of Insolvency Act 1986. 
vency test in the form adopted in Article $300^{15} \$ 5$ CCC is far from optimal, especially against the background of foreign legislation and the systemic context in which it is used, up to the point that now, up to some point, it is hard to decode the rules governing pay-outs form the simple joint-stock company. In view of the foregoing, it is to be feared that unless the Polish version of solvency test is substantially reformulated, its role of creditor protection will be devoid of any practical significance whereas it will most likely cause numerous problems in corporate practice or will be fully ignored by a vast number of market participants.

\section{REFERENCES}

Adamus, Rafał. Prawo upadtościowe. Komentarz. Warsaw: C.H. Beck, 2019. American Bar Association. Committee on Corporate Laws. Model Business Corporation Act: Official Text with Official Comment and Statutory Cross-References (December 2020). https://www.americanbar.org/content/dam/aba/administrative/business_law/corplaws/2020_mbca.pdf.

Artur, Nowacki. "Niewypłacalność płynności jako przesłanka ogłoszenia upadłości." Przeglad Prawa Handlowego 8 (September 2020): 4-12.

Bachner, Thomas. Creditor Protection in Private Companies Anglo-German Perspectives for a European Legal Discourse. Cambridge: Cambridge University Press, 2009.

Committee The State Bar of California. Revisions to Streamline and Update Corporation Code Provisions Relating to Distributions and Repurchases of Shares Legislative Proposal (bls-2011-01) (April 2010).

Engert, Andreas. "Life Without Legal Capital: Lesson from American Law." Working Paper, Ludwig Maximilians Universität München (27 February 2006): 1-56. https://papers.ssrn.com/sol3/papers.cfm?abstract_id=882842.

Filipiak, Patryk. In System Prawa Handlowego. Prawo restrukturyzacyjne i upadtościowe, edited by Anna Hrycaj, Andrzej Jakubecki, and Antoni Witosz. Warsaw: C.H. Beck, 2019.

Gajownik-Zienkiewicz, Jowita. "Kilka uwag o teście wypłacalności." Przeglad Prawa Handlowego 9 (September 2011): 55-56.

Hannigan, Brenda. Company Law. Oxford: Oxford University Press, 2018.

Haynes, Christopher I. "The Solvency Test: A New Era in Directorial Responsibility." Auckland University Law Review 7 (1996): 125-141. 
Heaton, John B. "Solvency Test." The Business Lawyer 62, no. 3 (2007): 9831006. http://www.jstor.org/stable/40688428.

Herbet, Andrzej. “Kapitał akcyjny prostej spółki akcyjnej i jego funkcje.” In Kodeks spótek handlowych po 20 latach, edited by Marek Leśniak, Bogusław Sołtys, and Maciej Skory. Wroclaw: Wolters Kluwer, 2021 (in print).

Komarnicki, Igor, "Ograniczenia wypłat na rzecz akcjonariuszy w prawie europejskim.” In Europejskie prawo spótek - t. I. Instytucje prawne dyrektywy kapitatowej, edited by Mirosław Cejmer, Jacek Napierała, and Tomasz Sójka. Cracow: C.H. Beck, 2004.

Kubiczek, Marcin, and Bartosz Sokół. "Metodyka badania płynnościowej przesłanki niewypłacalności w świetle jej prawnej definicji." Doradca Restrukturyzacyjny 1 (2016): 104-115.

Kuhner, Christoph. "The Future of Creditor Protection Through Capital Maintenance Rules in European Company Law." In Legal Capital in Europe, edited by Marcus Lutter. European Company and Financial Law Review, Special Volume 1 (2006): 341-364.

Mączyńska, Elżbieta. "Ocena kondycji przedsiębiorstwa: Uproszczone metody." Życie Gospodarcze 38 (1994): 42-45.

Mączyńska, Elżbieta, and Maciej Zawadzki. "Dyskryminacyjne modele predykcji upadłości przedsiębiorstw." Ekonomista 2 (2006): 205-235.

Marek, Mirosław, Paweł Multaniak, Błażej Piechowiak, and Anna Szymańska. In Postępowanie restrukturyzacyjne. Komentarz praktyczny. Wzory pism i przyktady postępowań restrukturyzacyjnych, edited by Andrzej Głowacki, and Cezary Zalewski. Warsaw: C.H. Beck, 2020.

Mazgaj, Marcin. In Kodeks spótek handlowych. Komentarz, edited by Zbigniew Jara. Warsaw: C.H. Beck, 2020.

Opalski, Adam. "Prosta spółka akcyjna - nowy typ spółki handlowej (część I)." Przeglad Prawa Handlowego 11 (November 2019): 4-16.

Patryk, Filipiak. In Prawo restrukturyzacyjne. Komentarz, edited by Patryk Filipiak, and Anna Hrycaj. Warsaw: Wolters Kluwer, 2020.

Payne, Jennifer. "Legal Capital in the UK Following the Companies Act 2006. Rationality In Company Law: Essays in Honour of D.D. Prentice, J. Armour and J. Payne, eds., Hart Publishing." Oxford Legal Studies Research Paper, no. 13 (October 2008): 1-45. https://ssrn.com/abstract=1118367.

Pellens, Bernhard, and Thorsten Sellholm. "Improving Creditor Protection Through IFRS Reporting and Solvency Tests." In Legal Capital in Europe, edited by Lutter Marcus. European Company and Financial Law Review, Special Volume 1 (2006): 365-391. 
Prusak, Błażej. Nowoczesne metody prognozowania zagrożenia finansowego przedsiębiorstw. Warsaw: Difin, 2005.

Rickford, Jonathan. "Reforming Capital. Report of the Interdisciplinary Group on Capital Maintenance." European Business Law Review 15 (April 2004): 919-1017.

Ross, Michael J. “Evaluation New Zealand's Companies Law.” Agenda: A Journal of Policy Analysis and Reform 1, no. 2 (1994): 189-196.

Scriggins, Larry. "The Model Business Corporations Act Financial Provisions: A Historical Snapshot." Law and Contemporary Problems 76 (Winter 2011): 121-128.

Wawer, Małgorzata. In Kodek spótek handlowych. Komentarz, edited by Jacek Bieniak, Michał Bieniak, Grzegorz Nita-Jagielski, Krzysztof Oplustil, Robert Pabis, Anna Rachwał, Marcin Spyra, Grzegorz Suliński, Marcin Tofel, Małgorzata Wawer, and Robert Zawłocki. Warsaw: C.H. Beck, 2020.

Zimmermann, Piotr. Prawo upadtościowe. Prawo restrukturyzacyjne. Komentarz. Warsaw: Wolters Kluwer, 2020.

Żurek, Michał. Reforma regulacji prawnej kapitatu zaktadowego spótki z ograniczona odpowiedzialnością. Problematyka ochrony wierzycieli. Warsaw: C.H. Beck, 2018. 
